\title{
KAJIAN ETNOBOTANI TUMBUHAN SEBAGAI BAHAN TAMBAHAN PANGAN SECARA TRADISIONAL OLEH MASYARAKAT DI KECAMATAN PEKUNCEN KABUPATEN BANYUMAS
}

\author{
Ari Apriliani, SuKarsa, HeXa Apriliana Hidayah
}

Fakultas Biologi, Universitas Jenderal Soedirman, Jalan dr. Suparno 63 Purwokerto 53122

A B S T R A C T

People can't detached from plants in fulfilling their needs, such as plant as food additives. This study aimed to know the types and parts of plants as food additives, and its benefits, as well as its utilization by people of Pekuncen District Banyumas Regency. This research used survey method with purposive random sampling and semi-structured interviews. Data were analyzed descriptively. The results of this study indicated 34 species of 19 familia plants used as food additives. The part of plants used as food additives were tubers, rhizomes, seeds, stems, leaves and fruits. Food additive plants were utilized as flavor enhancer, natural dye, preservatives and acid flavor. The plants were utilized by cooking, cuting, crushing, shredding, grinding, "dikeprek", roasting, boiling, and marinating.

KEY WORDS: plants, utilization, food additives

Penulis korespondensi: SUKARSA | email: esakarsa@yahoo.co.id

\section{PENDAHULUAN}

Etnobotani merupakan kajian mengenai interaksi antara masyarakat lokal dengan lingkungan alamnya, terutama mengenai penggunaan tumbuhan dalam kehidupan sehari-hari (Martin, 1998). Penggunaan tumbuhan dalam kehidupan sehari-hari antara lain dapat berupa tumbuhan sebagai bahan pangan. Cornelius (1984) menyatakan bahwa tumbuhan pangan adalah segala sesuatu yang tumbuh, hidup, berbatang, berakar, berdaun, dan dapat dimakan atau dikonsumsi oleh manusia.

Meningkatnya kesadaran masyarakat akan pentingnya hidup sehat, tuntutan masyarakat terhadap bahan pangan juga bergeser. Bahan pangan yang kini banyak diminati masyarakat bukan saja yang mempunyai komposisi gizi yang baik serta penampakan dan cita rasanya menarik, tetapi juga harus memiliki fungsi fisiologis tertentu bagi tubuh (Astawan 2003). Untuk membuat makanan yang lezat, menarik dan tahan lama diperlukan penanganan serta penambahan bahan tambahan pangan (BTP) yang tepat.

Bahan tambahan pangan (BTP) adalah bahan atau campuran bahan yang secara alami bukan merupakan bagian dari bahan baku pangan, tetapi ditambahkan ke dalam pangan untuk mempengaruhi sifat atau bentuk bahan pangan (Winarno, 1991). Cahyadi (2006) menyatakan bahwa tujuan penggunaan BTP di dalam pangan adalah untuk: 1) mengawetkan makanan dengan mencegah pertumbuhan mikroba perusak pangan atau mencegah terjadinya reaksi kimia yang dapat menurunkan mutu pangan; 2) membentuk makanan menjadi lebih baik, renyah dan lebih enak di mulut; 3) memberikan warna dan aroma yang lebih menarik sehingga menambah selera; 4) meningkatkan kualitas pangan dan 5) menghemat biaya.

Berdasarkan sumbernya, bahan tambahan pangan dapat digolongkan menjadi 2 golongan yakni bahan tambahan pangan alami dan buatan. Bahan tambahan pangan alami dipandang lebih aman bagi kesehatan dan mudah didapat, sedangkan bahan tambahan sintesis dikhawatirkan dapat menimbulkan efek samping terhadap kesehatan. Penggunaan bahan tambahan sintesis sebaiknya dengan dosis dibawah ambang batas yang telah ditentukan (Saparinto dan Hidayati, 2006).

Dalam kehidupan sehari-hari BTP sudah digunakan secara umum oleh masyarakat. Salah satunya yaitu masyarakat di Kecamatan Pekuncen. Kecamatan Pekuncen merupakan salah satu kecamatan di Kabupaten Banyumas yang terdiri dari 16 desa. Berdasarkan data curah hujan di Kecamatan Pekuncen, curah hujan tertinggi rata-rata yaitu 221 $\mathrm{mm}$, dengan curah hujan tahunan setinggi $2648 \mathrm{~mm}$ (BPS Kab. Banyumas, 2009 dalam Risdianto et al, 2012). Curah hujan yang cukup tinggi di Kecamatan Pekuncen menyebabkan daerah ini menjadi subur dengan keanekaragaman tumbuhan yang tinggi. Sebagian besar masyarakat Kecamatan Pekuncen Kabupaten Banyumas masih bergantung pada alam, terutama pada tumbuh-tumbuhan baik dimanfaatkan sebagai papan, obat tradisional dan pangan. Dengan keadaan tersebut, maka dimungkinkan masih banyak masyarakat Pekuncen yang menggunakan tumbuhan sebagai bahan tambahan pangan. Masyarakat Pekuncen dalam kehidupan sehari-hari untuk mengolah pangan tidak hanya sebagai makanan pokok tetapi pangan yang diolah dapat dijadikan lauk pauk, cemilan, kue dan masih banyak lagi tidak hanya dalam kehidupan sehari-hari, tapi dalam keadaan tertentu misalnya hajatan, selametan dan acara-acara tertentu masyarakat Pekuncen biasa menggunakan tumbuhan sebagai bahan pangan. Makanan pokok dan beberapa macam makanan tambahan wajib ada dalam acara-acara tersebut.

Tujuan yang ingin dicapai dari penelitian ini adalah untuk mengetahui: 
1. Jenis-jenis dan bagian-bagian tumbuhan yang dimanfaatkan sebagai bahan tambahan pangan oleh masyarakat Kecamatan Pekuncen di Kabupaten Banyumas

2. Manfaat dan cara pemanfaatan tumbuhan yang dimanfaatkan sebagai bahan tambahan pangan oleh masyarakat Kecamatan Pekuncen di Kabupaten Banyumas

\section{MET ODE}

Bahan yang digunakan dalam penelitian ini adalah tumbuhan yang dimanfaatkan sebagai bahan tambahan pangan oleh masyarakat Kecamatan Pekuncen di Kabupaten Banyumas.

Alat-alat yang digunakan dalam penelitian ini adalah bolpoin, pensil, kertas label, kamera, buku identifikasi, daftar pertanyaan dan kantong plastik. Penelitian ini dilakukan pada 8 desa dari 16 desa. Penelitian dilakukan selama satu bulan.

Penelitian dilakukan dengan menggunakan metode survei dengan teknik pengambilan sampel secara acak terpilih (purpossive random sampling) pada daerah yang telah ditentukan, sedangkan untuk pengumpulan data pemanfaatan tumbuhan secara tradisional dilakukan wawancara secara semi terstruktur menggunakan kuisioner dan pengamatan langsung di lapangan. Wawancara kepada 10 orang responden meliputi ibu rumah tangga dan penjual makanan. Identifikasi dilakukan terhadap tumbuhtumbuhan yang dimanfaatkan masyarakat di Kecamatan Pekuncen, Kabupaten Banyumas sebagai bahan tambahan pangan diidentifikasi guna mendapatkan nama ilmiahnya dengan menggunakan identifikasi Backer and Brink (1963; 1965; 1968), Heyne (1987) dan Effendi (1993).

Data jenis tumbuhan sebagai bahan tambahan pangan yang diperoleh dicatat nama daerahnya, kemudian dianalisis secara deskriptif seperti jenis tumbuhan yang dimanfaatkan, bagian tumbuhan yang dimanfaatkan, manfaat dan cara pemanfaatan.

Estimasi nilai manfaat (use value) suatu spesies untuk tumbuhan sebagai bahan tambahan pangan dihitung dengan menggunakan rumus menurut (Cotton, 1996) sebagai berikut :

$$
\mathrm{UVs}=\frac{\sum \mathrm{UVis}}{\text { is }}
$$

Keterangan :

UVs = nilai manfaat jenis s secara keseluruhan

Uvis = nilai manfaat jenis s yang ditentukan oleh informan $\mathrm{i}$

Is = jumlah total responden yang diwawancarai untuk jenis $\mathrm{s}$

\section{HASIL DAN PEMBAHASAN}

Berdasarkan hasil penelitian yang telah dilakukan di Kecamatan Pekuncen Kabupaten Banyumas ditemukan 34 jenis tumbuhan bahan tambahan pangan yang termasuk dalam 19 suku (Tabel 1.).

Hasil penelitian menunjukkan Cocos nucifera L., Carica papaya L., Cymbopogon citratus (DC) Stapf. Curcuma domestica Val., Zingiber officinale Roscoe. (Tabel 1) tumbuh tersebar merata di Kecamatan Pekuncen. Berdasarkan wawancara dengan masyarakat bahwa tumbuhan tersebut mempunyai banyak manfaat, mudah ditanam, dapat hidup dimana saja, dan tidak memerlukan perawatan khusus sehingga masyarakat menanamnya.
Beberapa jenis tumbuhan tertentu tidak ditemukan di lokasi penelitian tetapi digunakan sebagai bahan tambahan pangan dan masyarakat dapat memperolehnya dengan cara membeli dari warung atau pasar antara lain Allium cepa L., A. fistulosum L., A. sativum L, Coriandrum sativum L., Daucus carota L., Myristica fragans Houtt. dan Pangium edule Reinw. (Tabel 1). Berdasarkan wawancara dengan masyarakat, bahwa mereka merasa kesulitan dalam memperoleh bibit, tumbuhan susah ditanam dan kurangnya pengetahuan tentang membudidayakan atau cara menanam tumbuhan tersebut.

Jenis-jenis tumbuhan yang dimanfaatkan sebagai bahan tambahan pangan secara tradisional oleh masyarakat di Kecamatan Pekuncen Kabupaten Banyumas adalah sebagai berikut:

\section{Bawang merah (Allium cepa L.)}

Tanaman berumbi. Akar berserabut. Daun bentuk silindris, sedikit kecil, memanjang dan berongga. Masyarakat di seluruh lokasi penelitian memanfaatkan umbi bawang merah sebagai penyedap rasa, aroma dan bumbu dengan nilai manfaat sebesar 0,19 . Cara pemanfaatan: memotong atau mengiris tipis dan memasukan ke berbagai macam sayuran dan ada juga cara yang lain yaitu mengiris tipis bawang merah, digoreng dan dijadikan bawang goreng lalu ditaburkan ke masakan, contohnya kari, soto, bakso, nasi goreng. Bahan aktif yang memegang peranan penting dalam aroma, rasa dan bau pada bawang merah adalah hasil biosintesis dalam bentuk minyak atsiri yang disebut alinase yang terdiri dari campuran cystein, methionine, sulfur-allyl cystein sulfoxide, sulfur-methyl cystein sulfoxide, sulfur 10peptida (Soedomo, 2006). Masyarakat juga memanfaatkan kulit bawang merah untuk pewarna telur menjadi cokelat kemerahan yaitu dengan cara hasil kupasan kulit bawang merah dimasukan ke air rebusan telur. Lestari, 2011 menyatakan bahwa bawang merah merupakan salah satu tumbuhan yang sering digunakan sebagai zat warna alami. Kulit bawang merah mengandung zat warna alam yaitu senyawa antosianin dan flaponoida.

\section{Daun bawang (Allium fistulosum L.)}

Habitus herba, semusim. Akar serabut pendek. Daun bulat, memanjang dan berlubang seperti pipa. Nilai manfaat dari daun bawang adalah 0,15 dan daun bawang dimanfaatkan masyarakat di seluruh lokasi penelitian sebagai penyedap rasa dan aroma. Bagian yang dimanfaatkan yaitu batang dan daun, dengan cara dipotong kecil-kecil lalu dimasukkan atau ditaburkan pada makanan, bisa juga dimasukkan adonan tepung yaitu untuk membuat berbagai jenis gorengan misalnya mendoan, tahu dan bakwan. Menurut Fransica et al., (2006) daun bawang mengandung minyak atsiri yang menyebabkan bau harum.

\section{Bawang putih (Allium sativum L.)}

Habitus berupa herba, semusim. Batang semu. Akar serabut. Daun pipih memanjang. Umbi bawang putih dimanfaatkan oleh masyarakat di lokasi penelitian sebagai bumbu, penyedap rasa dan aroma dengan nilai manfaat sebesar 0,18 . Cara pemanfaatan sebagai bumbu yaitu umbi dihaluskan dengan berbagai jenis bahan yang lain (bawang merah, kemiri, ketumbar, merica dan lain-lain.) dan dicampurkan ke masakan. Pemanfaatan sebagai penyedap rasa dan aroma yaitu dengan cara umbi "dikeprek" terlebih 
dahulu lalu dipotong halus dan ditumis di penggorengan dengan sedikit minyak goreng Hidangan yang menggunakan bawang putih antara lain daging, ikan, sayur-sayuran, bumbu gorengan. Wibowo (2006) menambahkan, bahwa bawang putih memiliki cita rasa sangat khas yang ditimbulkan oleh komponen sulfur yang ada dalam minyak volatil bawang putih. Jenis senyawa yang menentukan bau khas bawang putih yaitu allicin.

Tabel 1. Jenis tumbuhan bahan tambahan pangan yang termasuk dalam 19 suku

\begin{tabular}{|c|c|c|c|c|c|}
\hline No & Jenis & Nama lokal & Suku & Desa & Nilai manfaat \\
\hline 1 & Allium сера L. & Bawang merah & \multirow{3}{*}{ Amaryllidaceae } & - & 0,19 \\
\hline 2 & A. fistulosum $\mathrm{L}$ & Daun bawang & & - & 0,15 \\
\hline 3 & A. sativum $\mathrm{L}$. & Bawang putih & & - & 0,18 \\
\hline 4 & Apium graveolens L. & Seledri & \multirow{4}{*}{ Apiaceae } & $1,2,5,8$ & 0,10 \\
\hline 5 & Coriandrum sativum L. & Ketumbar & & - & 0,10 \\
\hline 6 & Cuminum Cyminum L. & Jinten Putih & & - & 0,03 \\
\hline 7 & Daucus carota L. & Wortel & & - & 0,13 \\
\hline 8 & Cocos nucifera $\mathrm{L}$. & Kelapa & Arecaceae & $1,2,3,4,5,6,7,8$ & 0,30 \\
\hline 9 & Dracaena angustifolia Roxb. & Suji & Asparagaceae & $1,2,4,6,8$ & 0,20 \\
\hline 10 & Ananas comosus L. (Merr). & Nanas & Bromeliaceae & $1,2,3,4,5,8$ & 0,10 \\
\hline 11 & Carica papaya $\mathrm{L}$. & Pepaya & Caricaceae & $1,2,3,4,5,6,7,8$ & 0,07 \\
\hline 12 & Aleurites moluccana L. Willd. & Kemiri & Euphorbiaceae & 2 & 0,10 \\
\hline 13 & Pangium edule Reinw. & Kluwak & Flacourtiaceae & - & 0,03 \\
\hline 14 & Cinnamomum burmannii (Nees \& Th. Nees) Blume. & Kayu manis & Lauraceae & $1,2,4,5,8$ & 0,14 \\
\hline 15 & Tamarindus indica $\mathrm{L}$. & Asam jawa & Fabaceae & $3,5,8$ & 0,05 \\
\hline 16 & Myristica fragrans Hout. & Pala & Myristicaceae & - & 0,10 \\
\hline 17 & Psidium guajava $\mathrm{L}$. & Jambu Biji & \multirow{3}{*}{ Myrtaceae } & $1,2,3,5,6,8$ & 0,07 \\
\hline 18 & Syzygium aromaticum $\mathrm{L}$. & Cengkeh & & $1,2,3,5,8$ & 0,19 \\
\hline 19 & Syzygium polyanthum (Wight) Walp. & Salam & & $1,3,6,8$ & 0,15 \\
\hline 20 & Avverhoa bilimbi L. & Belimbing wuluh & Oxalidaceae & $1,2,4,5$ & 0,06 \\
\hline 21 & Pandanus amarylifolius Roxb. & Pandan & Pandanaceae & $2,3,5,7,8$ & 0,19 \\
\hline 22 & Piper nigrum L. & Merica & Piperaceae & $1,3,5$ & 0,20 \\
\hline 23 & Cymbopogon citratus (DC) Stapf. & Serai & \multirow[t]{2}{*}{ Poaceae } & $1,2,3,4,5,6,7,8$ & 0,13 \\
\hline 24 & Citrus aurantifolia Swingle. & Jeruk nipis & & $1,2,4,6$ & 0,16 \\
\hline 25 & C. hystrix (DC) & Jeruk purut & \multirow[t]{2}{*}{ Rutaceae } & $2,5,7$ & 0,15 \\
\hline 26 & Capsicum annuum L. & Cabai merah & & $1,3,5,8$ & 0,18 \\
\hline 27 & C. frustescens $\mathrm{L}$ & Cabai rawit & \multirow[t]{2}{*}{ Solanaceae } & $1,2,3,5,7,8$ & 0,10 \\
\hline 28 & Solanum lycopersicon Mill. & Tomat & & $1,2,3,5,8$ & 0,20 \\
\hline 29 & Alpinia galanga L. Sw. Willd. & Lengkuas & \multirow{6}{*}{ Zingiberaceae } & $1,2,4,5,7$ & 0,17 \\
\hline 30 & Curcuma domestica Val. & Kunyit & & $1,2,3,4,5,6,7,8$ & 0,40 \\
\hline 31 & Elettaria cardamomum L. Maton & Kapulaga & & $1,2,3,5,8$ & 0,05 \\
\hline 32 & Etlingera elatior (Jack) R.M.Sm. & Kecombrang & & $1,2,5,7,8$ & 0,10 \\
\hline 33 & Kaempferia galanga $L$. & Kencur & & $2,3,5,8$ & 0,17 \\
\hline 34 & Zingiber officinale Roscoe & Jahe & & $1,2,3,4,5,6,7,8$ & 0,30 \\
\hline
\end{tabular}

\section{Seledri (Apium graveolens L.)}

Habitus berupa herba. Akar tunggang dan memiliki serabut akar yang menyebar ke samping. Batang beralur, beruas, bercabang banyak, dan hijau. Daun majemuk menyirip ganjil. Nilai manfaat dari daun seledri sebesar 0,10 dan seledri hanya dimanfaatkan sebagai penyedap rasa dan aroma pada makanan. Bagian yang dimanfaatkan yaitu batang dan daun, dengan cara dipotong kecil-kecil lalu dimasukkan atau ditaburkan pada makanan, bisa juga dimasukkan adonan tepung yaitu untuk jenis gorenggorengan. Oktaviani (2012), menambahkan bahwa aroma yang khas dari seledri berasal dari sejumlah komponen mudah menguap dari minyak atsiri yang dikandungnya. Kandungan utama seledri adalah butilftalida dan butilidftalida sebagai pembawa aroma utama. Daun dan tangkai daun seledri mengandung steroid seperti stigmasterol dan sitosterol.

\section{Ketumbar (Coriandrum sativum L.)}

Habitus semak semusim dan berakar tunggang. Batang berkayu lunak, beralur, dan berlubang. Daun majemuk, menyirip. Buah berbentuk bulat, hijau (muda), kuning kecokelatan (tua). Biji bulat dan berwarna kuning kecokelatan. Masyarakat di seluruh lokasi penelitian memanfaatkan biji ketumbar hanya sebagai penyedap rasa dan aroma dengan nilai manfaat sebesar 0,10. Cara pemanfaatan: biji ketumbar dihaluskan dengan cara diuleg dengan tambahan bumbu lain (bawang putih, pala, merica). Ketumbar mempunyai aroma yang khas, aromanya disebabkan oleh komponen kimia yang terdapat dalam minyak atsiri yang terdiri dari monoterpenoid (Sutarno dan Sumadi, 2001).

\section{Jintan Putih (Cuminum cyminum L.)}

Habitus berupa terna dengan batang ramping bercabang, daun menyirip atau menyirip ganda. Bunga kecil, putih atau merah muda, dan bergerombol pada payungan bunga. Buah longkah (achene) menggelendong lateral atau oval dan mengandung satu biji. Nilai manfaat jintan putih sebesar 0,03, karena biji jintan putih dimanfaatkan sebagai penyedap rasa dan aroma hanya pada beberapa masyarakat desa yaitu Petahunan, Pasiraman Lor dan Tumiyang. Pemanfaatan tersebut diperoleh secara turun temurun. Cara pemanfaatan: ditumbuk sampai halus dengan bumbu lain (bawang putih, kemiri, kunyit, lengkuas dan lain-lain) dan dimasukkan ke hidangan seperti kari, ayam dan daging Aroma yang khas dari jinten putih berasal dari dihidrokuminaldehid dan monoterpen. Bau dan rasa jinten putih adalah kuat dan hangat (Sutarno dan Sumadi, 2001). 


\section{Wortel (Daucus carota L.)}

Tanaman berumbi semusim. Batang sangat pendek sehingga hampir tidak nampak, batang bulat, tidak berkayu, agak keras, berbulu dan berwarna hijau. Daun majemuk menyirip ganda dua atau tiga. Bunga majemuk, bentuk cawan. lonjong, putih. Akar tunggang, membentuk umbi, oranye. Masyarakat di desa Pasiraman Lor dan Karang Kemiri memanfaatkan umbi wortel sebagai pewarna. Umbi wortel juga dimanfaatkan oleh masyarakat di seluruh lokasi penelitian sebagai penyedap rasa dan aroma dengan nilai manfaat sebesar 0,13. Cara pemanfaatan umbi wortel sebagai pewarna yaitu wortel diparut, diperas dan air hasil perasan ditambahkan ke adonan mie, sedangkan pemanfaatannya sebagai penyedap rasa yaitu wortel dipotong, ukuran potongan sesuai keinginan sendiri lalu dimasukkan ke masakan. Menurut Rubatzky dan Yamaguchi (1997) kantong minyak dalam ruang antarsel perisikel pada umbi wortel mengandung minyak esensial yang menyebabkan bau dan aroma yang khas wortel. Akar tunggang menyimpan sukrosa dan gula lain dalam jumlah yang cukup banyak. Gula-gula yang terdapat pada wortel umumnya terdiri dari sukrosa, glukosa, fruktosa dan maltosa. $\alpha$-dan $\beta$-karoten adalah pigmen karotenoid utama yang menyebabkan warna kuning dan jingga pada wortel.

\section{Kelapa (Cocos nucifera L.)}

Batang tumbuh lurus, tidak bercabang, bulat dan permukaannya beralur-alur. Daun majemuk menyirip genap. Buah batu. Bunga majemuk. Akar serabut. Masyarakat di lokasi penelitian memanfaatkan air dan daging kelapa sebagai pewarna, penyedap rasa, pemberi aroma dan masyarakat di Petahunan dan Karang Kemiri juga memanfaatkan kelapa sebagai pengawet dan mempunyai nilai manfaat sebesar 0,30. Masyarakat di lokasi penelitian biasa memanfaatkan kelapa sebagai pewarna yaitu dengan cara daging kelapa diparut dan diperas akan menghasilkan santan kelapa berwarna putih dan dimasukan ke dalam masakan dan santan ini juga memberikan aroma yang khas pada makanan. Hal ini sesuai dengan pernyataan Kort (1979) bahwa santan merupakan emulsi lemak dalam air dan dapat berwarna putih susu karena partikelnya berukuran lebih besar dari satu micron. Santan distabilisasi secara alamiah oleh protein (globulin dan albumin) dan fosfolipida. Warna cokelat dari gula merah disebabkan karena terjadinya reaksi pencokelatan non enzimatis yaitu reaksi maillard dan karamelisasi. Yasin (2013) juga menambahkan bahwa santan mempunyai rasa lemak, sehingga membuat rasa masakan menjadi lebih sedap dan gurih dengan aroma khas kelapa yang harum (adanya senyawa nonylmethylketone). Air nira yang dimasak sampai matang dan dipadatkan akan menjadi gula yang berwarna cokelat, memberikan rasa manis dan aroma pada makanan. Kelapa sebagai pengawet cara pengolahannya yaitu daging kelapa diparut dan disangrai biasanya dijadikan serundeng. Daging kelapa dapat dimanfaatkan sebagai minyak goreng yaitu dengan cara daging yang sudah tua diparut dan hasil parutan ditambahkan air lalu dimasak, diaduk-aduk sampai kandungan air dari santan terpisah. Nanti akan tersisa ampas dan minyak, minyak inilah yang digunakan untuk memasak. Nira mengandung zat gula seperti sakarosa, glukosa dan fruktosa serta karbohidrat lainnya sehingga rasanya manis dan memberikan aroma yang khas (Nurhayati, 1996).

\section{Daun suji (Dracaena angustifolia Roxb.)}

Perdu tegak atau pohon kecil. Batang tegak, berkayu. Daun tunggal, ujung meruncing. Bunga majemuk, di ujung cabang, bentuk tandan, putih keunguan. Buah bulat berwarna hijau. Nilai manfaat daun suji sebesar 0,20 dan dimanfaatkan sebagai pewarna, pemberi aroma dan penghias makanan oleh masyarakat Petahunan, Semedo, Pekuncen, Pasiraman Lor, Cikembulan dan Karang Klesem. Pemanfaatan tumbuhan tersebut terjadi secara turun temurun dan dari pengetahuan masyarakat yang terus berkembang. Cara pemanfaatan daun suji sebagai pewarna alami yaitu daun suji dipotong kecil-kecil dan ditumbuk lalu diperas. Air hasil perasan dimasukan ke bahan makanan. Hal ini didukung oleh Istichomah (2004), bahwa suji dipakai sebagai pewarna alami makanan karena menghasilkan warna hijau yang dihasilkan oleh pigmen yang bernama khlorofil. Pemanfaatan daun suji sebagai pemberi aroma pada makanan yaitu daun suji dicuci bersih dan dimasukkan langsung ke makanan, begitu pula cara pemanfaatan daun suji sebagai penghias makanan yaitu cukup memotong daun sesuai keinginan kita dan dihiaskan pada aneka kue. Prasetyo et al (2012), bahwa senyawa-senyawa organik lain yang terkandung dalam daun suji adalah saponin steoroid, minyak atsiri, alkaloid, flavonoid, dan tanin. Minyak atsiri menyebabkan aroma khas pada daun suji.

\section{Nanas (Ananas comosus L.)}

Herba. Batang pendek, tertutup oleh daun-daun dan akar. Buah bulat panjang, berdaging, ketika muda berwarna hijau, sudah masak berwarna kuning. Masyarakat di Desa Semedo, Tumiyang, Pekuncen, Pasiraman Lor dan Karang Klesem memanfaatkan buah nanas sebagai pelunak daging dan pemberi rasa asam dengan nilai manfaat sebesar 0,10. Mereka memanfaatkan nanas dengan cara memarut nanas muda dan dicampurkan pada masakan. Warsiki (1993) menambahkan bahwa nanas mengandung citric dan malic acid yang memberi rasa manis dan asam pada buahnya.

\section{Pepaya (Carica papaya L.)}

Pohon atau semak, sebagian besar tidak bercabang. Batang bulat berongga. Daun tunggal, besar, bertangkai panjang. Biji kecil, banyak. Buah dan daun pepaya dimanfaatkan sebagai pelunak daging oleh masyarakat Desa Petahunan, Semedo, Karang Kemiri, Tumiyang, Pasiraman Lor dan Karang Klesem dengan nilai manfaat yang diperoleh sebesar 0,07 . Cara pemanfaatannya yaitu memotong kecil-kecil buah pepaya muda lalu dimasukkan langsung ke masakan daging. Ada juga yang memanfaatkan bagian daunnya yaitu daging dibungkus dan diremas-remas menggunakan daun pepaya. Hal tersebut sesuai pernyataan Armia (2012), bahwa papain merupakan enzim yang terkandung di dalam getah buah pepaya muda yang berfungsi untuk melunakkan daging. Dalam getah pepaya terkandung enzim-enzim protease (pengurai protein) yaitu papain dan kimopapain. Papain merupakan satu dari enzim paling kuat yang dihasilkan oleh seluruh bagian tanaman pepaya.

\section{Kemiri (Aleurites moluccana (L) Willd)}

Habitus berupa pohon, batang tegak, berkayu, cokelat. Daun tunggal dan berwarna hijau. Bunga majemuk berwarna putih. Buah bulat telur, bergaris-garis. Biji bulat, berkulit keras, berdaging, berminyak dan berwarna putih kecokelatan. Nilai manfaat dari kemiri sebesar 0,10 karena masyarakat di seluruh lokasi penelitian memanfaatkan biji kemiri hanya sebagai penambah rasa dan aroma. Cara pemanfaatannya yaitu biji kemiri ditumbuk dengan bumbu lain (bawang putih, kemiri, ketumbar dan lain-lain) dan dimasukan ke masakan (kari, daging dan ikan). 
Penambahan biji kemiri pada masakan bertujuan supaya masakan lebih enak dan gurih, hal ini sesuai dengan Rahma et al., (2012) bahwa adanya asam amino non esensial yang menonjol pada kemiri yaitu asam glutamate dan asam aspartat. Keberadaan asam glutamate yang memberikan rasa nikmat pada kemiri dan dijadikan sebagai pengganti penyedap masakan seperti MSG.

\section{Kluwak (Pangium edule Reinw.)}

Habitus berupa pohon, berbatang lurus. Daun berbentuk jantung. Bunga berwarna putih kehijauan. Buah lonjong, daging putih dan lunak. Biji bertempurung, asimetris. Biji kluwak dimanfaatkan oleh masyarakat Desa Petahunan Kecamatan Pekuncen hanya sebagai penyedap rasa dan pewarna pada makanan dengan nilai manfaat sebesar 0,03. Cara pemanfaatannya yaitu biji kluwak dihaluskan dengan bumbu lain (merica, pala, bawang putih dan lain-lain) dan dimasukkan ke masakan. Kluwak ini akan memberikan rasa, aroma yang khas dan warna hitam pada masakan. Komponen asam glutamat pada kluwak sangat besar kontribusinya pada cita rasa rawon. Keberadaan asam glutamat secara alami pada kluwak akan mencegah ketergantungan kepada MSG (monosodium glutamat) sebagai bahan penyedap (Astawan, 2009).

\section{Kayu Manis (Cinnamomum burmannii (Nees \&Th. Nees)} Blume)

Habitus semak atau pohon, batang berwarna keabu-abuan. Daun tunggal yang duduknya tersebar, kadang-kadang berhadapan, tidak mempunyai penumpu. Buah buni memanjang berwarna merah kecokelatan. Masyarakat di Desa Petahunan, Karang Kemiri, Pekuncen, Pasiraman Lor, Cikembulan dan Karang Klesem memanfaatkan kulit batang kayu manis sebagai penyedap rasa dan aroma dengan nilai manfaat 0,14 . Cara pemanfaatannya yaitu kulit batang yang sudah dikeringkan dicuci dan dimasukkan kemasakan. Sutarno dan Sumadi (2001) menambahkan bahwa rasa dan bau tertentu pada kayu manis ditentukan oleh kandungan minyak aromatik yang mudah menguap.

\section{Asam jawa (Tamarindus indica L.)}

Batang kayu padat dan keras. Kulit batang kasar dan memecah. Daun majemuk menyirip genap, terletak berseling. Bunga dalam tandan. Buah polong yang menggelembung. Daging buah asam manis dan melengket. Nilai manfaat asam jawa sebesar 0,05 dan masyarakat Desa Semedo, Tumiyang, Karang Kemiri dan Pasiraman Lor memanfaatkan buah asam jawa hanya sebagai penambah rasa asam pada makanan. Cara pemanfaatannya yaitu buah asam direndam dan air rendaman dipakai untuk rujak, pecel, sayur asem. Daging buah asam jawa mengandung 8$14 \%$ asam tartarat, $30-40 \%$ gula, serta sejumlah kecil asam sitrat dan kalium bitaetrat sehingga berasa sangat masam (Rukmana, 2005).

\section{Pala (Myristica fragrans Houtt.)}

Habitus berupa pohon. Akar tunggang. Batang menyilinder, tegak lurus. Daun elips, membundar dan lonjong. Bunga berkelamin dua (hermaphrodit), malai. Buah bulat berwarna kuning. Biji pala dimanfaatkan oleh masyarakat di seluruh lokasi penelitian sebagai penyedap rasa dan aroma dengan nilai manfaat sebesar 0,10. Mereka memanfaatkan biji pala dengan cara mengiris sedikit biji pala dan dihaluskan dengan bumbu lain yaitu bawang putih, bawang merah, pala, merica dan lain-lain. Masakan yang biasa menggunakan pala yaitu daging, ikan dan masakan kuah bersantan. Sutarno dan Sumadi (2001) menambahkan bahwa minyak atsiri pala berwarna kuning pucat-jernih seperti air, pedas, berbau aromatik dan komponen utama minyak pala adalah hidrokarbon monoterpen 61-88\%, monoterpen oksigenat 5-15\% dan eter aromatik (miristisin, elemisin, safrola) $2-18 \%$.

\section{Jambu biji (Psidium guajava L.)}

Batang tua bulat dan keras, kulit batang licin berwarna cokelat kemerahan dengan lapisan yang tipis dan mudah terkelupas jika sudah mengering. Daun tunggal. Bunga tumbuh di ketiak daun atau pada pucuk ranting. Masyarakat Desa Petahunan, Semedo, Karang Kemiri, Pekuncen, Pasiraman Lor dan Karang Klesem memanfaatkan daun jambu biji sebagai pewarna telur dengan nilai manfaat sebesar 0,07. Mereka memanfaatkannya dengan cara daun jambu biji direbus bersama telur. Hal tersebut sesuai Mayangsari (2012), bahwa daun jambu biji memiliki banyak kandungan senyawa, seperti polifenol, karoten, flavonoid dan tannin. Flavonoida merupakan kelompok flavonol turunan senyawa benzena yang dapat digunakan sebagai senyawa dasar zat warna alam. Tanaman yang mengandung flavonoid akan memberikan warna kuning sampai cokelat.

\section{Cengkeh (Syzygium aromaticum L.)}

Pohon, berkayu keras, bulat, permukaan kasar. Daun berbentuk bulat telur memanjang dan meruncing berwarna hijau. Bunga dan buah akan muncul pada ujung ranting daun dengan tangkai pendek serta bertandan. Cengkeh dimanfaatkan oleh masyarakat desa Petahunan, Semedo, Karang Kemiri, Tumiyang dan Karang Klesem sebagai penyedap rasa dan aroma serta penghilang bau amis dan mempunyai nilai manfaat 0,19 . Bagian yang dimanfaatkan yaitu buah dan daunnya. Mereka memanfaatkannya dengan cara buah cengkeh dikeringkan, di masukkan langsung ke masakan (daging dan ikan). Cara pemanfaatan daun cengkeh yaitu daun yang masih muda ditumbuk dan dicampurkan dengan bumbu lain (kunyit, bawang putih, jahe dan lain-lain) di masukan ke masakan. Begitu pula pada buah cengkeh langsung dimasukan saja tanpa ditumbuk. Hal ini didukung oleh Regiyana (2000), bahwa eugenol adalah senyawa utama pada minyak esensial cengkeh dan senyawa inilah yang memberikan aroma khas cengkeh.

\section{Salam (Syzygium polyanthum (Wigh) Walp)}

Pohon atau perdu. Batang bulat, kulit batang berwarna coklat abu-abu, memecah atau bersisik. Berdaun tunggal, bersilang berhadapan. Bunga kebanyakan banci. Biji bulat berwarna cokelat. Nilai manfaat daun salam sebesar 0,15 dan dimanfaatkan oleh masyarakat desa Petahunan, Semedo, Karang Kemiri, Tumiyang, Pekuncen dan Karang Klesem sebagai pemberi aroma dan pengawet. Cara pemanfaatannya sangat sederhana yaitu daun salam yang kering atau masih segar di masukan langsung ke masakan seperti sayur asam, sayur lodeh, pepes, gulai, kari, nasi kuning, sup, bubur gurih dan lain sebagainya. Aroma khas daun salam disebabkan oleh minyak atsiri yang terkandung didalamnya (Arinawati, 2000). Penelitian secara in vitro membuktikan bahwa ekstrak daun salam dapat menghambat pertumbuhan 4 bakteri-bakteri patogen, seperti Salmonella, Vibrio cholera, Eschericia coli, serta Staphylococcus aureus (Fitri, 2007).

\section{Belimbing wuluh (Averrhoa bilimbi Linn.)}

Pohon kecil. Daun majemuk menyirip ganjil. Buah bulat lonjong bersegi hingga seperti torpedo, kulit berkilap dan 
tipis, hijau kekuningan dan sangat asam. Masyarakat Desa Petahunan, Pekuncen, Pasiraman Lor, Tumiyang dan Cikembulan memanfaatkan buah belimbing wuluh sebagai pengasam/penetral dengan nilai manfaat sebesar 0,06. Caranya yaitu buah belimbing wuluh yang masih muda dimasukkan langsung ke masakan atau belimbing wuluh direbus terlebih dahulu lalu air hasil rebusan ditambahkan ke masakan. Aroma khas buah belimbing wuluh merupakan interaksi antara senyawa nonanal, asam nonanoat, dan (E)2-Nonenal. Sedangkan senyawa yang bertanggung jawab terhadap rasa pada buah belimbing wuluh adalah (Z)-3heksenol (Lathifah, 2008).

\section{Pandan wangi (Pandanus amaryllifolius Roxb.)}

Tumbuhan perdu yang semi menjalar. Batang semi menjalar, pada pangkal keluar berupa akar. Daun tunggal, tipis dan berwarna hijau kekuningan. Bentuk bunga majemuk, buah batu menggantung berbentuk bola. Nilai manfaat daun pandan wangi adalah 0,19 dan daun pandan dimanfaatkan sebagai pewarna, pemberi aroma yang khas dan penghias makanan oleh masyarakat Desa Petahunan, Semedo, Pekuncen, Tumiyang, Pasiraman Lor dan Cikembulan. Cara pemanfaatan sebagai pewarna yaitu daun pandan dicuci hingga bersih, potong kecil-kecil dan ditumbuk lalu diperas. Air hasil perasan ditambahkan ke bahan pangan yang akan diwarnai. Hal tersebut didukung oleh Hapsari dan Wahyu (2010), bahwa sumber penghasil pewarna pada daun pandan yang digunakan sebagai pewarna alami adalah klorofil. Cara pemanfaatan sebagai pemberi aroma sangat sederhana yaitu daun pandan yang sudah bersih langsung dimasukan ke masakan. Begitu pula dengan daun pandan sebagai penghias, cukup potong daun pandan sesuai selera dan dihiaskan pada aneka macam kue (Lampiran 1.). Buttery et al,. (1983) menambahkan bahwa komposisi utama yang menyebabkan aroma pada pandan wangi tidak diketahui dengan pasti. Kemungkinan senyawa utama penyusun aroma pada daun pandan wangi adalah 2asetil-1-pirolin (2AP).

\section{Merica/lada (Piper nigrum L.)}

Habitus herba, semak dan menjalar. Batang berwarna abuabu tua, beruas-ruas. Daun tunggal tidak berpasangan, bertangkai, bulat telur. Buah bulat, berwarna merah (masak), berlendir. Biji merica dimanfaatkan oleh masyarakat di seluruh lokasi penelitian sebagai penyedap aroma, pemberi rasa pedas dan segar dengan nilai manfaat sebesar 0,20. Cara pemanfaatan sebagai penyedap aroma, pemberi rasa pedas dan segar yaitu biji merica ditumbuk atau diuleg dengan bumbu lain (bawang putih pala, kemiri dan lain-lain) dan ditambahkan ke masakan, biasanya pada waktu memasak daging, ikan, sop, dan bumbu masakan lainnya. Menurut Rismunandar (1987), bahwa aroma yang timbul pada lada disebabkan oleh minyak atsiri yang mengandung monoterpene, sesquiterpene, monoterpene-0 dan seqiuiterpene-0. Sifat kimiawi lada adalah pedas, berbau khas, dan aromatik karena mengandung senyawa piperin.

\section{Serai (Cymbopogon citratus (DC). Stapf.)}

Batang bergerombol dan berumbi, berongga, putih, bersifat kaku dan mudah patah. Daun kesat, panjang, runcing, berwarna hijau. Masyarakat di seluruh lokasi penelitian memanfaatkan batang serai sebagai bumbu dan pengawet makanan dengan nilai manfaat sebesar 0,13. Cara pemanfaatannya yaitu batang serai ditumbuk atau "dikeprek" lalu masukan ke masakan seperti daging dan ikan. Hal ini sesuai dengan pernyataan Rahman et al,.
(2008), bahwa daun dan tangkai serai dapur mengandung minyak atsiri 1,6\%. Minyak atsiri serai dapur mempunyai komponen utama yang terdiri dari geranial (45.2\%), neral $(32.4 \%)$ dan mirsen (10.6\%). Minyak atsiri yang mengandung senyawa dari golongan terpena, sinamaldehida, linalool, sitral, sitronelal, eugenol, dan fenol mempunyai daya antibakteri yang kuat. Minyak atsiri dari tanaman serai memiliki senyawa antibakteri terhadap Eschericia coli dan Staphylococcus aureus.

\section{Jeruk nipis (Citrus aurantiifolia (Christm.) Swingle)}

Pohon kecil, batang berkayu, berduri, keras. Daun majemuk. Bunga majemuk/tunggal dan berwama putih kekuningan. Buah bulat. Biji banyak, kecil-kecil, licin, bulat telur sungsang. Nilai manfaat jeruk nipis sebesar 0,16 dan masyarakat Desa Petahunan, Semedo, Pekuncen, Pasiraman Lor dan Cikembulan memanfaatkan jeruk nipis sebagai pengasam/penetral, penghilang bau amis dan penambah aroma. Bagian yang dimanfaatkan yaitu buah dan daun. Cara pemanfaatannya yaitu bagian buah diperas ke makanan (soto). Daun jeruk nipis juga dimanfaatkan sebagai pemberi aroma pada makanan yaitu dengan cara daun jeruk nipis dicuci sampai bersih lalu dimasukan ke masakan hal tersebut sesuai dengan pernyataan Razak et al (2013), bahwa keasaman pada buah jeruk nipis disebabkan oleh kandungan asam organik berupa asam sitrat. asam sitrat di jeruk nipis sebanyak 7-7,6\%. Bagian buah selain sebagai pengasam bisa juga dimanfaatkan untuk penghilang bau amis, caranya yaitu buah diperaskan ke bagian ikan atau daging yang akan dimasak. Astarini et al, (2010) menambahkan bahwa tanaman marga Citrus merupakan salah satu tanaman penghasil minyak atsiri yang merupakan suatu substansi alami yang telah dikenal memiliki efek sebagai antibakteri dan menghasilkan aroma yang khas. Minyak atsiri yang dihasilkan oleh tanaman yang berasal dari marga Citrus sebagian besar mengandung terpen, siskuiterpen alifatik, turunan hidrokarbon teroksigenasi, dan hidrokarbon aromatik

\section{Jeruk purut (Citrus hystrix D.C.)}

Batang tegak, bulat, berduri, hijau kotor. Daun tunggal, berseling, lonjong, tepi berringgit, ujung meruncing. Bunga majemuk, bentuk tandan di ketiak daun berwarna putih. Buah bulat, permukaan berkerut berwarna hijau. Biji bulat telur, putih. Masyarakat di desa Petahunan, Semedo, Karang Kemiri, Tumiyang, Cikembulan dan Karang Klesem memanfaatkan buah dan daun jeruk purut sebagai penyedap rasa, aroma dan penghilang bau amis dengan nilai manfaat yang diperoleh sebesar 0,15. Cara pemanfaatan jeruk purut sebagai penyedap rasa dan aroma yaitu bagian daun dicuci terlebih dahulu dan dimasukan ke masakan atau dipotong kecil-kecil dan dimasukan ke makanan seperti gado-gado atau bumbu pecel. Pemanfatan buah jeruk purut sebagai penghilang bau amis yaitu diperas dan lumuri kebagian daging atau ikan. Kandungan daun jeruk purut yaitu minyak atsiri. Kandungan senyawa kimia yang utama dari minyak daun jeruk purut adalah senyawa sitronelal 81,49\% (Mayasari et al,. 2013).

\section{Cabai merah (Capsicum annuum L.)}

Habitus berupa semak. Akar tunggang. Batang tumbuh tegak atau menyebar, hijau sampai hijau kecokelatan. Daun berbentuk ovate dan berwarna hijau muda sampai hijau tua. Buah muda berwarna hijau tua, setelah masak menjadi merah cerah. Masyarakat di seluruh lokasi penelitian memanfaatkan cabai merah sebagai penyedap rasa dan pewarna alami dengan nilai manfaat 0,18. Mereka 
memanfaatkan cabai merah sebagai penyedap rasa dengan cara menumbuk sampai halus atau mengiris kecil-kecil dan langsung dimasukan ke masakan (ayam, telur balado, aneka sambal, saus, dan sebagai campuran masakan yang pedas lainnya). Cabai merah juga dimanfaatkan sebagai pewarna alami pada masakan dengan cara ditumbuk sampai halus lalu masukan ke masakan dan akan memberikan warna merah pada kuah masakan. Cabai hijau adalah cabe merah besar yang dipanen saat warnanya masih hijau dan cabai hijau ini juga dimanfaatkan oleh masyarakat di lokasi penelitian sebagai penyedap rasa. Cara pemanfaatannya yaitu cabai hijau dipotong sesuai keinginan lalu dimasukan ke masakan seperti oseng tempe dan oseng sayur-sayuran. Yasin (2009) menyatakan bahwa cabai merah mengandung senyawa alkaloid dan capsaicin yaitu memberikan rasa pedas yang kuat. Warna merah pada cabai merah berasal dari kandungan pigmen karotenoid, yaitu capsanthin, capsorubin, lutein, zeaxanthin, carotene, dan cryptoxantin. Karotenoid merupakan suatu pigmen berwarna oranye, merah, atau kuning serta larut dalam minyak (lipida).

\section{Cabai rawit (Capsicum frutescens L.)}

Tumbuhan perdu/semak. Batang bulat, halus dan bercabang banyak. Daun berbentuk bulat telur. Bunga tunggal yang berbentuk bintang. Buah bulat pendek dengan ujung runcing/berbentuk kerucut. Biji banyak dan bulat pipih. Nilai manfaat cabai rawit sebesar 0,10 dan masyarakat di seluruh lokasi penelitian memanfaatkan cabai rawit hanya sebagai penyedap rasa. Bagian yang dimanfaatkan yaitu buah, dengan cara cabai rawit diiris atau potong kecil-kecil lalu dimasukkan ke dalam masakan atau bisa juga cabai rawit ditumbuk dengan bumbu lain misalnya bawang putih dan ditambahkan ke masakan contohnya tambahan masakan sayuran, rujak, sambal. Jika cabai dibelah, maka akan menemukan tangkai putih di dalamnya yang mengandung zat capsaicin yang seperti minyak dan menyengat sel-sel pengecap lidah. Zat inilah yang mengakibatkan cabai menjadi pedas dan panas di lidah ketika mengkonsumsinya serta membuat orang ketagihan atau kecanduan saat menyantap makanan (Prasetyawati, 2010). Cabai rawit juga mengandung hormon endorphin yang membuat makanan terasa lebih nikmat (Nafiza, 2013).

\section{Tomat (Solanum lycopersicon Mill.)}

Tomat merupakan tanaman herba semusim. Akar tunggang. Batang silindris dan bercabang, berwarna hijau dan berambut. Daun majemuk menyirip ganjil, berwarna hijau tua. Bunga sempurna, berwarna kuning. Buah buni, berdaging, berwarna merah, kuning dan oranye. Buah tomat dimanfaatkan oleh masyarakat di seluruh lokasi penelitian sebagai pewarna dan pemberi rasa asam pada makanan dan diperoleh nilai manfaat sebesar 0,20. Cara pemanfaatannya yaitu buah tomat digoreng dan dicampurkan dengan cabai biasanya untuk sambal. Pemanfaatan untuk rasa asam pada masakan yaitu tomat yang sudah bersih dipotong dan dimasukan ke dalam masakan atau makanan contohnya sop, sayur asem, bumbu sate. Hal ini sesuai dengan pernyataan Winarno dan Arman (1981, bahwa pigmen utama buah tomat adalah karoten (kuning) dan likopen (merah). Asam organik utama yang terdapat pada buah tomat adalah asam malat dan asam sitrat. Asam sitrat inilah yang menyebabkan tomat terasa segar.

\section{Lengkuas (Alpinia galanga (L.) Willd.)}

Habitus semak. Batang semu. Daun langset dan memanjang. Buah buni dengan bentuk cenderung membulat dan keras. Masyarakat di seluruh lokasi penelitian memanfaatkan rimpang lengkuas sebagai bumbu dan pengawet dengan nilai manfaat sebesar 0,17. Cara pemanfaatan lengkuas sebagai bumbu yaitu lengkuas dicuci, dihaluskan dengan cara ditumbuk dan dimasukkan ke masakan atau iris tipistipis lengkuas dan dimasukkan langsung ke masakan seperti daging, ikan dan hidangan berkuah. Sinaga (2013) menyatakan bahwa rimpang lengkuas rasanya tajam pedas, menggigit dan berbau harum karena kandungan minyak atsirinya. Rimpang lengkuas sebagai pengawet yaitu dengan cara rimpang diparut dan disangrai biasanya dijadikan serundeng ayam. Hal ini sesuai dengan Rahayu (1999), bahwa ekstrak lengkuas memiliki aktivitas terhadap 5 bakteri uji yang umum mengkontaminasi makanan yaitu Vibrio cholera, Pseudomonas aeruginosa, Listeria monocytogenes, Staphylococcus aures dan Bacillus cereus serta pada 3 kapang perusak pangan yaitu Aspergillus flavus, Rhizopus oligosporus dan Penicillium funiculosum.

\section{Kunyit (Curcuma domestica Val.)}

Habitus berupa semak. Batang semu, tegak, bulat, membentuk rimpang dengan warna hijau kekuningan. Daun tunggal, bentuk bulat telur (lanset). Bunga majemuk. Kulit luar rimpang berwarna jingga kecokelatan, buah merah jingga kekuning-kuningan. Rimpang kunyit dimanfaatkan oleh masyarakat di seluruh lokasi penelitian sebagai peyedap rasa dan aroma, pewarna alami makanan, pengawet makanan dan menghilangkan bau amis dengan nilai manfaat sebesar 0,40 . Cara pemanfaatan kunyit sebagai penyedap rasa, aroma dan menghilangkan bau amis yaitu dengan cara rimpang kunyit dihaluskan dan ditambahkan dengan bumbu lain (bawang putih, daun cengkeh, pala dan lain-lain) ke masakan seperti gulai, ikan, daging ayam, opr ayam dan masakan yang bersantan. Cara pemanfaatan kunyit sebagai pewarna alami adalah kunyit dicuci, ditumbuk atau diparut lalu diperas dan ditambahkan ke makanan atau kunyit ditumbuk sampai halus dan dimasukkan langsung ke masakan, contohnya yaitu nasi kuning, aneka macam bumbu gorengan, kare dan sebagainya. Pemanfaatan kunyit untuk pengawet alami yaitu dengan cara kunyit dihaluskan dengan bumbu lain seperti bawang putih, bawang merah dan daun salam dimasukkan ke masakan contohnya daging ayam. Naufalin dan Herastuti (2012), menyatakan bahwa rimpang kunyit mempunyai fungsi sebagai bahan rempah karena kandungan minyak atsirinya dan sebagai bahan pewarna karena kandungan kurkuminnya. Bubuk kunyit telah terbukti dapat menghambat pertumbuhan mikroba Bacillus subtilis, Escherichia coli dan Enterococcus faecalis. Hal ini menunjukkan bahwa selain sebagai rempah dan pewarna, kunyit dapat sekaligus sebagai pengawet yang aman untuk makanan. Zat aktif pada kunyit yang memiliki efektivitas sebagai antioksidan adalah kurkumin.

\section{Kapulaga (Elettaria cardamomum (L). Maton)}

Daun tunggal berbentuk lanset, ujung runcing dengan tepi rata. Batang semu. Bunga majemuk bentuk bonggol terletak di pangkal batang. Buah bulat memanjang, terdapat dalam tandan kecil-kecil, pendek berwarna putih kekuningan atau kuning. Nilai manfaat kapulaga sebesar 0,05 dan hanya dimanfaatkan sebagai penambah aroma oleh masyarakat di Desa Petahunan, Semedo, Tumiyang dan Karang Klesem. Cara pemanfaatannya yaitu buah kapulaga dikeringkan, kemudian setelah kering dimasukkan kemasakan biasanya masakan yang bersantan atau berkuah.Sutarno dan Sumadi (2001) menambahkan bahwa aroma sedap dari kapulaga berasal dari minyak atsiri. 


\section{Kecombrang (Etlingera elatior (Jack) R.M.Sm)}

Habitus berupa semak tahunan. Batang berbentuk semu gilig membesar di pangkalnya tumbuh tegak dan banyak. Rimpang tebal berwarna krem kemerah jambuan ketika masih muda. Daun tunggal, lanset, ujung dan pangkal runcing. Bunga majemuk, bentuk bongkol, berwarna kemerahan. Kecombrang dimanfaatkan sebagai pemberi cita rasa oleh masyarakat Desa Petahunan, Semedo, Karang Kemiri, Cikembulan dan Karang Klesem dengan nilai manfaat yang diperoleh 0,10 . Bagian yang dimanfaatkan yaitu bunga dan batangnya. Cara pemanfaatan bagian bunga biasanya dikukus atau langsung ditambahkan ke masakan begitu pula bagian batang biasanya ditumbuk tapi tidak sampai halus dan ditambahkan dengan bumbu lain (bawang putih, laos, kemiri dan lain-lain) lalu dimasukkan ke masakan contohnya pecel dan masakan daging. Kecombrang dapat dimanfaatkan sebagai pemberi cita rasa dikarenakan mengandung minyak atsiri, fenolik, flavonoid, terpena, asam lemak, ester asam lemak tertentu, dan alkaloid. Pada minyak atsiri yang bagian utamanya terpenoid. Zat inilah penyebab wangi, harum, atau bau yang khas pada minyak tumbuhan. Secara ekonomi, senyawa tersebut penting sebagai rempahrempah senyawa cita rasa di dalam industri makanan (Harbone, 1987).

\section{Kencur (Kaempferia galanga L.)}

Terna kecil. Daun tunggal, bergelombang, tangkai pendek, pelepah terbenam dalam tanah, berwarna putih. Akar serabut. Rimpang pendek, cokelat, berbentuk jari dan tumpul. Daging rimpang tidak keras, rapuh, mudah patah dan bergetah. Rimpang kencur dimanfaatkan sebagai penyedap rasa dan aroma oleh masyarakat di seluruh lokasi penelitian dengan nilai manfaat sebesar 0,17. Mereka memanfaatkan rimpang kencur dengan ditumbuk sampai halus atau rimpang kencur diiris kecil-kecil dan dimasukkan langsung ke masakan. Masakan yang biasa menggunakan rimpang kencur antara lain tegean atau sop, pecel, lotek atau rujak, sop atau tegean. Menurut Pramono (1994), bahwa rimpang kencur digunakan sebagai rempah karena mengandung minyak atsiri yang menyebabkan aroma khas.

\section{Jahe (Zingiber officinale Roscoe.)}

Tumbuh berumpun. Batang semu, tidak bercabang, berbentuk bulat, tegak, daun tunggal. Rimpang bercabangcabang tidak teratur, berserat, dan berbau khas aromatik. Rimpang jahe dimanfaatkan sebagai penyedap rasa, pemberi aroma khas dan menghilangkan bau amis oleh masyarakat di seluruh lokasi penelitian dan nilai manfaat yang diperoleh sebesar 0,30. Cara pemanfaatan rimpang jahe sebagai penyedap rasa dan aroma yaitu jahe dibersihkan, ditumbuk atau "dikeprek" ditambahkan dengan bumbu lain (kunyit, merica, pala, garam dan lainlain) dan dimasukkan ke dalam hidangan seperti daging, ikan, bubur kacang ijo. Pemanfaatan rimpang jahe sebagai penghilang bau amis yaitu jahe ditumbuk sampai halus dengan bumbu lain (bawang putih, pala, merica, kemiri dan lain-lain) lalu di lumuri ke bagian daging atau ikan. Hal tersebut sesuai dengan pernyataan Yasin (2013) bahwa, sifat khas jahe disebabkan adanya minyak atsiri (minyak menguap) dan oleoresin (tidak menguap). Aroma harum jahe disebabkan oleh minyak atsiri, sedangkan oleoresinnya menyebabkan rasa pedas dan pahit. Komponen utama minyak atsiri jahe yang menyebabkan bau harum adalah zingiberen dan zingiberol. Komponen dalam oleoresin jahe terdiri atas gingerol dan zingiberen, shagaol, minyak atsiri dan resin. Pemberi rasa pedas dalam jahe yang utama adalah zigerol. Jahe juga dimanfaatkan sebagai pengawet oleh masyarakat Kecamatan Pekuncen, cara pemanfaatannya yaitu dengan cara jahe dibersihkan lalu dihaluskan dan dimasukkan ke masakan. Ekstrak jahe memiliki aktivitas antimikroba terhadap bakteri pathogen dan perusak pangan yaitu Salmonella typi, Vibrio cholera 01 dan Escherichia coli 0157:h7 dengan konsentrasi 5-7,5 $\mathrm{mg} / \mathrm{ml}$ (Radiarti, 2002).

\section{KESIMPULAN DAN SARAN}

Berdasarkan hasil penelitian ini, maka dapat disimpulkan :

1. Jenis tumbuhan yang dimanfaatkan sebagai bahan tambahan pangan antara lain Allium cepa L., $A$. fistulosum L, A. sativum L., Apium graveolens L., Coriandrum sativum L., Cuminum cyminum L., Daucus carota L., Cocos nucifera L., Dracaena angustifolia Roxb., Ananas comosus L., Carica papaya L., Aleurites moluccana (L.) Willd., Pangium edule Reinw., Cinnamomum burmannii (Nees \&Th. Nees) Blume., Tamarindus indica L., Myristica fragrans Houtt., Psidium guajava L., Syzygium aromaticum L., Syzygium polyanthum (Wight) Walp., Avverhoa bilimbi L., Pandanus amarylifolius Roxb., Piper nigrum L., Cymbopogon citratus (DC) Stapf., Citrus aurantifolia Swingle., C. hystrix DC., Capsicum annuum L., C. frutescens L., Solanum lycopersicum Mill., Alpinia galanga (L.) Sw. Willd., Curcuma domestica Val., Elettaria cardamomum (L.) Maton, Etlingera elatior (Jack) R.M.Sm., Kaempferia galanga L. dan Zingiber officinale Roscoe. Bagian tumbuhan yang dimanfaatkan sebagai bahan tambahan pangan adalah umbi, rimpang, biji, batang, daun dan buah.

2. Pemanfaatan tumbuhan bahan tambahan pangan antara lain sebagai penyedap rasa dan aroma, pewarna alami, pengawet, pengasam/ penetral. Cara pemanfaatannya yaitu dengan cara dimasak, dipotong, diuleg, ditumbuk, diparut, "dikeprek", disangrai, direbus, dan direndam.

Perlu diadakan penelitian pada beberapa Kecamatan lainnya di Kabupaten Banyumas sebagai perbandingan jenis-jenis tumbuhan yang dimanfaatkan sebagai bahan tambahan pangan.

\section{DAFT AR REFERENSI}

Aeni EN. 2009. Kutu putih (Hemiptera: Pseudococcidae) pada tanaman nanas (Ananas Comosus (Linn.) Merr.) di desa Bumiayu Kecamatan Jalancagak, Kabupaten Subang [skripsi]. Fakultas Pertanian, Institut Pertanian Bogor-Bogor.

Arinawati M. 2000. Identifikasi dan Karakterisasi Komponen Aroma Daun Salam Szygyium polyanthum (Weight) Walp.). [thesis]. Program Pascasarjana,Institut Pertanian Bogor-Bogor.

Teknologi Hasil Pertanian: Papain [Internet]. 2012. Armia R [diakses tanggal 20 November 2013]. Tersedia di: http://tehape08.Word press.com/2012/07/26/papain/.

Astawan M. 2003. Pangan fungsional untuk kesehatan yang optimal. Jakarta: Bumi Aksara.

Kluwak Kaya Antioksidan [Internet]. 2009 [diakses tanggal 22 November 2013]. Tersedia di : http://cybermed.cbn.net.id/cbprtl/cybermed/detail.aspx? $\mathrm{x}=\mathrm{Nu}$ trition\&y=cybermed $\% 7 \mathrm{C0} \% 7 \mathrm{C0} \% 7 \mathrm{C} 6 \% 7 \mathrm{C} 532$.

Buttery RG, Ling LC, Juliano BO, Turnbough JC. 1983. Cooked rice aroma and 2- acetyl-1-pyrroline. J. Agric. Food Chem. 31: 823 826. 
Cahyadi W. 2006. Analisis dan aspek kesehatan bahan tambahan pangan. Cetakan Pertama. Jakarta: PT. Bumi Aksara.

Cornelius B. 1984. Analisa zat warna yang digunakan untuk makanan di daerah bandung. Bandung: Institut Teknologi Bandung.

Fransisca D, Irda F, Komar R. 2006. Telaah kandungan kimia ekstrak etil asetat bawang daun (Allium fistulosum L.). Bandung: Sekolah Farmasi. Institut Teknologi Bandung; Laporan Penelitian.

Hapsari L, Wahyu M. 2010. Pembuatan konsentrasi zat warna untuk bahan makanan dari daun pandan (Pandanus amaryllifolius Roxb) dan biji kesumba (Bixa Orellana Linn) beserta penerapannya [skripsi]. Universitas Sebelas Maret. Surakarta.

Harborne JB. 1987. Metode fitokimia [diterjemahkan oleh Padmawinata K, Soediro I. Bandung: Penerbit Institut Teknologi Bandung. hal 147.

Istichomah K. 2004. Pengaruh lama penyimpanan daun terhadap komposisi dan kandungan klorofil daun suji (Pleomele angustifolia N. E. Brown) [skripsi]. Fakultas Sains dan Matematika, Universitas Kristen Satya Wacana-Salatiga.

Kort MJ. 1979. Colour in the sugar industry. Duban, South Africa: Sugar Milling Research Institute, University Of Natal.

Lathifah QA. 2008. Uji efektifitas ekstrak kasar senyawa antibakteri pada buah belimbing wuluh (Averrhoa bilimbi L.) dengan variasi pelarut. Malang: Fakultas Sains dan Teknologi Universitas Islam Negeri Malang.

Pencelupan Dengan Zat Warna Alami dari Kulit Bawang Merah. 2011. Lestari $\mathrm{N}$ [diakses tanggal 20 November 2013]. Tersedia di: http://nadyalestari.blogspot.com/2011/04/pencelupandengan-zat-warna-alami-dari.html.

Martin GJ. 1998. Etnobotani: sebuah manual pemeliharaan manusia dan tumbuhan [diterjemahan oleh Maryati Mohamed]. Edisi Bahasa Melayu. Malaysia: Natural History Publications (Borneo) Sdn. Bhd.

Pembuatan Zat Warna Alam Dari Daun Jambu Biji. 2012. Mayangsari P [diakses tanggal 23 November 2013]. Tersedia di: http://www.scribd.com/doc/101349685/zat-warna-alamdari-daun-jambu-biji.

Mayasari D, Afghani J, Wibowo MA. 2013. Pengaruh variasi waktu dan ukuran sampel terhadap komponen minyak atsiri dari daun jeruk purut (Citrus Hystrix Dc.). Pontianak. JKK. 2(2): 74-77.

Pangan dasar-bumbu dan rempah. 2013. Nafiza Z [diakses tanggal 21 November 2013]. Tersedia di: http://zulfanazifa. blogspot.com/2013/02/bumbu-dan-rempah.html.

Naufalin R, Herastuti SR. 2012. Pengawet alami pada produk pangan. Purwokerto: Tim UPT Percetakan dan Penerbitan Universitas Jenderal Soedirman.

Nurhayati. 1996. Mempelajari kontribusi flavor gula merah pada pembentukan flavor kecap manis [skripsi]. Fakultas Teknologi Pertanian, Institut Pertanian Bogor-Bogor
Pramono S. 1994. Etil P-Metoksisinamat: identitas rimpang kencur (Kaempferia galanga L.). Makalah Seminar Nasional VI Tumbuhan Obat Indonesia; Bandung.

Prasetyawati NP. 2010. Analisa kandungan vitamin C pada cabai rawit (Capsicum Frustescens L.) berbagai varietas [skripsi]. Universitas Muhamadiyah Semarang-Semarang.

Radiarti L. 2002. Mekanisme penghambatan virulensi bakteri enteropatogen oleh ekstrak rimpang jahe (Zingiber officinale Roscoe.) [disertasi]. Program Pasca Sarjana, Institut Pertanian Bogor-Bogor.

Rahma Y, Prassita IA, Asep K, Nisrina AS, Adi J, Hari. 2012. makalah teknologi pengolahan rempah "kemiri". Bandung: Universitas Padjajaran.

Razak A, Djamal A, Revilla G. 2013. Uji daya hambat air perasan buah jeruk nipis (Citrus aurantifolia L.) terhadap pertumbuhan bakteri Staphylococcus aureus secara in vitro. Jurnal Kesehatan Andalas. 2(1).

Regiyana Y. 2000. Kajian daya insektisida campuran ekstrak bunga cengkeh (Syzygium aromaticum) dan ekstrak kayu manis (Cinnamomum burmannii) terhadap perkembangan serangga hama gudang Sitophilus zeamais Motsch [skripsi]. Fakultas Teknologi Pertanian, Institut Pertanian Bogor-Bogor.

Rismunandar. 1987. Lada, budidaya dan tata niaganya. Jakarta: Penebar Swadaya.

Rubatzky VE, Yamaguchi M. 1998. Sayuran dunia : prinsip, produksi, dan gizi. Jilid 2. Bandung: Institut Teknologi Bandung. hal 292.

Rukmana R. 2005. Budidaya asam jawa. Yogyakarta: Kanisius.

Saparinto C, Hidayati D. 2006. Bahan tambahan pangan. Yogyakarta: Kanisius.

Alpinia galanga (L.) Willd. Lengkuas [Internet]. 2013. Sinaga E: [diakses tanggal 19 November 2013]. Tersedia di: http://bebas. vlsm. org/v12/artikel/ttg_tanaman_obat/unas/Lengkuas.pdf.

Soedomo RP. 2006. Seleksi induk tanaman bawang merah. Bandung: Balai Penelitian Tanaman Sayur. J. Hort. 16(4): 269282.

Sutarno H, Sumadi A. 2001. Tantangan pengembangan dan fakta jenis tanaman rempah. Bogor: Yayasan Prosea.

Warsiki E. 1993. Bahan pengisi terhadap desain produk tepung instan sari buah nanas (Ananas comosus L. Merr ) [skripsi] Fakultas Teknologi Pertanian, Institut Pertanian Bogor-Bogor.

Wibowo S. 2006. Budidaya bawang, bawang putih, bawang merah, bawang bombay. Jakarta: Penebar Swadaya. hal 80-81.

Winarno FG, Arman M. 1981. Fisiologi lepas panen. Jakarta: Sastra Hudaya.

Yasin YY. 2009. Penggunaan pupuk daun dan retardan paclobutrazol terhadap pertumbuhan dan hasil tanaman cabai merah (Capsicum Annuum) dalam polybag [skripsi]. Fakultas Pertanian, Institut Pertanian Bogor-Bogor. 